\title{
JIRILL KBPBRAIWATAI
}

Diterbitkan oleh Program Studi Ilmu Keperawatan Fakultas Ilmu Kesehatan Universitas Muhammadiyah Malang bekerjasama dengan Persatuan Perawat Nasional Indonesia (PPNI) Kota Malang

\author{
Editor In Chief \\ Edi Purwanto, MNg \\ Managing Editor \\ Muhammad Rosyidul 'Ibad, M.Kep \\ Editorial Boards \\ Yoyok Bekti Prasetyo, M.Kep, Sp.Kom \\ Henny Dwi Susanti, M.Kep, Sp. Kep, Mat \\ Indah Dwi Pratiwi, MNg \\ Nur Lailatul Masruroh, MNS \\ Anggraini Dwi Kurnia, MNS \\ Risa Herlianita, MNS
}

\section{Alamat Redaksi}

Program Studi Ilmu Keperawatan Fakultas Ilmu Kesehatan Universitas Muhammadiyah Malang Kampus II Jl. Bendungan Sutami 188A Malang 65145 Jawa Timur

Telp. (0341) 552443, 551149 Fax. (0341) 582060 Email jurnal.keperawatan@umm.ac.id

\section{Alamat Organisasi Profesi}

Jl. Ijen 77C Malang

Telp. (0341) 566075 Fax. (0341) 571388 Email: contact@poltekkes-malang.ac.id 